NBER WORKING PAPER SERIES

\title{
BEHAVIORAL FINANCE IN CORPORATE GOVERNANCE - INDEPENDENT DIRECTORS, NON-EXECUTIVE CHAIRS, AND THE IMPORTANCE OF THE DEVIL'S ADVOCATE
}

\author{
Randall Morck \\ Working Paper 10644 \\ http://www.nber.org/papers/w10644
NATIONAL BUREAU OF ECONOMIC RESEARCH
1050 Massachusetts Avenue
Cambridge, MA 02138 \\ July 2004
}

I am grateful for helpful comments and suggests by seminar participants at rhus University, the University of Alberta, the Journal of Management and Governance Symposium at the Università Cattolica Sacro Cuore of Milan, the National Bureau of Economic Research Universities Conference on Behavioral Corporate Finance, and the University of Toronto; and especially for suggestions by Malcolm Baker, Terry Burnham, Lorenzo Caprio, Steve Kaplan, Ricky Ruback, Andrei Shleifer, Henry Tosi, and Jeff Wurgler. This research was funded in part by the Social Sciences and Humanities Research Council. The views expressed herein are those of the author(s) and do not necessarily reflect the views of the National Bureau of Economic Research.

2004 by Randall Morck. All rights reserved. Short sections of text, not to exceed two paragraphs, may be quoted without explicit permission provided that full credit, including notice, is given to the source. 
Behavioral Finance in Corporate Governance - Independent Directors, Non-Executive Chairs, and the Importance of the Devil's Advocate

Randall Morck

NBER Working Paper No. 10644

July 2004, Revised October 2007

JEL No. G3

\title{
ABSTRACT
}

The Common Law, parliamentary democracy, and academia all institutionalize dissent to check undue obedience to authority; and corporate governance reformers advocate the same in boardrooms. Many corporate governance disasters could often be averted if directors asked hard questions, demanded clear answers, and blew whistles. Work by Milgram suggests humans have an innate predisposition to obey authority. This excessive subservience of agent to principal, here dubbed a "type II agency problem", explains directors' eerie submission. Rational explanations are reviewed, but behavioral explanations appear more complete. Experimental work shows this predisposition disrupted by dissenting peers, conflicting authorities, and distant authorities. Thus, independent directors, chairs, and committees excluding CEOs might induce greater rationality and more considered ethics in corporate governance. Empirical evidence of this is scant - perhaps reflecting problems identifying genuinely independent directors.

\author{
Randall Morck \\ Faculty of Business \\ University of Alberta \\ Edmonton, CANADA T6G 2R6 \\ and NBER \\ randall.morck@ualberta.ca
}




\section{Loyalty means nothing unless it has at its heart the absolute principle of self-sacrifice.}

Woodrow T. Wilson

\section{Introduction}

Misplaced loyalty lies at the heart of numerous recent scandals in corporate governance. Corporate officers and directors, who should have known better, put loyalty to a dynamic Chief Executive Officer above duty to shareholders and obedience to the law. The officers and directors of Enron, Worldcom, Hollinger, and almost every other allegedly misgoverned firm could have asked questions, demanded answers, and blown whistles, but did not. Ultimately they sacrificed their careers and reputations for their CEOs.

Loyalty is an important virtue. It makes possible the large hierarchical organizations that underpin national economies: armies, government bureaucracies, political parties and corporations. But loyalty - to political ideologues, religious zealots, ethnic purists, and other militants - also underlies the most horrific chapters in history books. ${ }^{1}$ Corporate governance scandals are minor misdemeanors in this company, but the underlying problem of misplaced loyalty is the same.

Much work in empirical social psychology suggests that loyalty is hardwired into human behavior. Milgram $(1963,1974)$ shows that a human subject suppresses internal ethical standards surprisingly readily if these conflict with loyalty to an authority figure. This accords well with officers and directors' stalwart loyalty to misguided or errant CEOs, even under clear signs of impending financial doom. Milgram argues that loyal behavior stimulates feelings of well-being, and that this reflects evolutionary pressure on early human societies, when obedience to authority wrought social organization that raised survival odds (Hobbes, 1652).

In the modern world, more nuanced obedience to authority may be required. Corporate governance reformers, in particular, seek to weaken this innate response at selective points in corporate hierarchies. Milgram (1974) finds that dissenting peers and rival authorities undermine 
subjects' loyalty, and stimulate independent moral reasoning. Corporate governance reforms that envision independent directors (dissenting peers) and non-executive chairs (alternative authority figures) aspire to a similar effect on corporate boards - a fostering of debate to expose flawed policies before they become lethal - and thereby render corporate governance disasters rarer. In this vein, the Higgs Report proposes that listed company boards in the United Kingdom have non-executive chairs and senior independent directors, and the Sarbanes Oxley reforms in the United States require that boards contain enough independent directors to staff key board committees.

In light of these findings from social psychology, the inability of economics and finance to detect consistent linkages between board independence and corporate performance is puzzling. ${ }^{2}$ There are two plausible reasons for this.

One is that insufficient time has elapsed to show the effects of active independent directors. Many of the directors classified as independent in corporate proxy statements may in fact be deeply beholden to the CEO. The Higgs report finds that almost half the so-called independent directors on British boards were recruited by the CEO through personal contacts or friendships. A mere four percent had a formal interview. This renders nominally independent directors beholden to CEOs. As more stringent definitions of independence apply, a clearer relationship with firm performance may emerge.

A second plausible reason is that behavioral constraints on board independence are deep. Deeper reforms, like letting institutional investors and public shareholders nominate candidates for elections to boards, may thus be needed to foster genuinely independent directors and board chairs. Institutional investors too are only tenuously linked to firm performance. This may reflect governance problems within institutional investors (Lakonishok et al. 1992) or their inability at present to affect many boards.

\footnotetext{
${ }^{1}$ See e.g. Laski (1919).

${ }^{2}$ See e.g. Hermalin and Weisbach (2003) for a recent survey.
} 
More generally, behavioral arguments, heretofore restricted within finance to explaining asset pricing anomalies (Shleifer, 1999; Baker and Wurgler, 2007), may illuminate issues in other branches of financial economics, such as corporate governance. ${ }^{3}$

\section{The Milgram Experiment}

The first empirical evidence for an innate loyalty response in human behavior is a series of social psychology experiments begun in1961 by Stanley Milgram (1963, 1974), then an Assistant Professor of psychology at Yale (Blass, 2004). Milgram constructed a box, depicted in Figure 1, featuring electric switches labeled "15 volts”, “30 volts”, “45 volts”, and so on up to “450 volts”. The voltages were also labeled with terms ranging from "slight" through "very strong" to "extreme intensity”, “danger severe”, and "XXX”. Wires led from this box to various parts of the body of a professional actor, the "learner" shown in Figure 1B, who was paid to feign increasingly painful electrocution as the real subject of the experiment threw switches marked with increasing voltages. The box contained a noise maker to mimic the buzz of surging electric currents.

Each subject was told (falsely) that the "learner" was the subject of the experiment and asked to assist the experimenter. The purpose of the experiment was explained as studying "the effects of punishment on learning and memory." The real subjects of the experiment were ordinary citizens of New Haven, CT. attracted by advertisements of cash for participation in psychology experiments. The subjects thus felt a financial obligation to Milgram as well as a sense of participating in important research at a leading university. Milgram wore a lab coat to impress this image.

\footnotetext{
${ }^{3}$ A large strategy literature posits behavioral regularities in boardrooms. For example Westphal and Stern $(2006,2007)$ and references therein demonstrate networking effects in director selection. Behavioral explanations of governance issues also enter the finance literature - e.g. Shleifer and Vishny (2003) on merger waves, Baker et al. (2007) on capital spending, and others.
} 
The subject was told he or she would serve as a "teacher", and was seated before the panel of switches. The "learner" was asked a series of questions, to which he sometimes gave incorrect answers. Each time this occurred, the "teacher" was to apply a larger electric shock to the actor, who feigned increasing pain. Milgram (1974, p. 4) describes the actor’s script: “At 75 volts, the "learner" grunts. At 120 volts he complains verbally; at 150 he demands to be released from the experiment. His protests continue as the shocks escalate, growing increasingly vehement and emotional. At 285 volts his response can only be described as an agonized scream.”

\section{Figure 1. The Experimental Design}

The setup in Stanley Milgram's original obedience experiments at Yale University in the early 1960s.

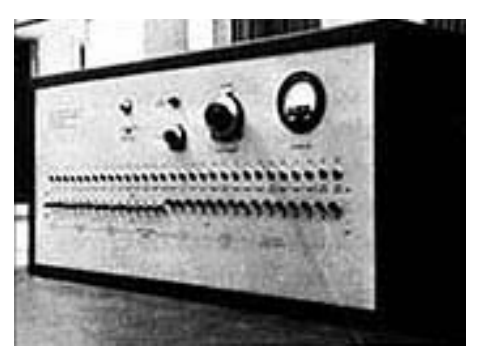

Panel A. The bogus shock generator contains a buzzer and has wires running to the “teacher's” seat.

Source: Milgram (1974).

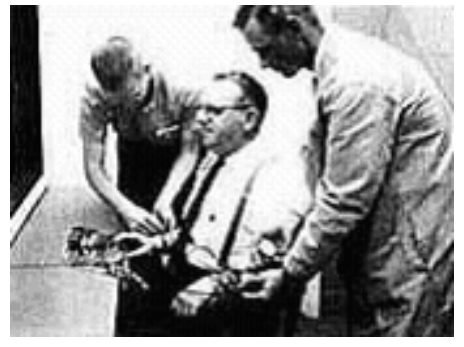

Panel B. The "teacher" (real experimental subject) helps strap in the "learner" (actor) and apply bogus electrodes

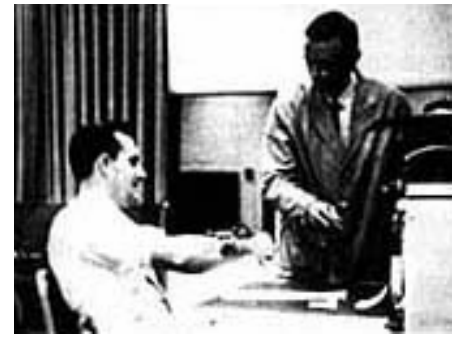

Panel C. The teacher is taught to operate the bogus shock generator

Milgram initially believed most Americans would quickly break off from the experiment. He initially intended to replicate the procedure in Germany to see if there was a cultural difference that might explain the widespread complicity of ordinary Germans in wartime atrocities. Milgram was astonished at the results of a "test run”, in which Yale students dutifully electrocuted perfect strangers when told to do so. Milgram dismissed the results as the behavior of "Yalies”.

But the full fledged experiment, using ordinary Americans, generated similar results. Ordinary Americans seem perfectly willing to send high voltage electric shocks through a complete stranger if ordered to do so by an authority figure. 
Figure 2 summarizes the results of the Milgram experiment. One hundred percent of ordinary Americans are willing to send electric shocks through an experimental subject, up through 135 volts, when the "learner" demands to be released. At that point, about twenty percent stop obeying. Eighty percent of Americans continue administering shocks labeled "very strong" and "intense", up through two hundred and eighty-five volts, when the "learner" begins screaming in agony. A bit over sixty percent of ordinary Americans obediently administer electric shocks all the way up to four hundred and fifty volts, despite labels like "extreme intensity", “danger severe”, and "XXX” next to the voltage figures on the control panel.

The Milgram experiment has been replicated many times in many countries, including Germany - see Miller (1986) and Blass $(1998,2000)$ for a review of this literature; and Merritt and Helmreich (1996), Tarnow (2000), and others for other related work - and has been replicated by this author. Its generality as a description of human nature is now beyond doubt.

Figure 2. Obedience Rates, Basic Milgram Experiment Fraction of ordinary Connecticut residents who directed high voltage electric shocks through the bodies of perfect strangers when ordered to do so by a psychologist.

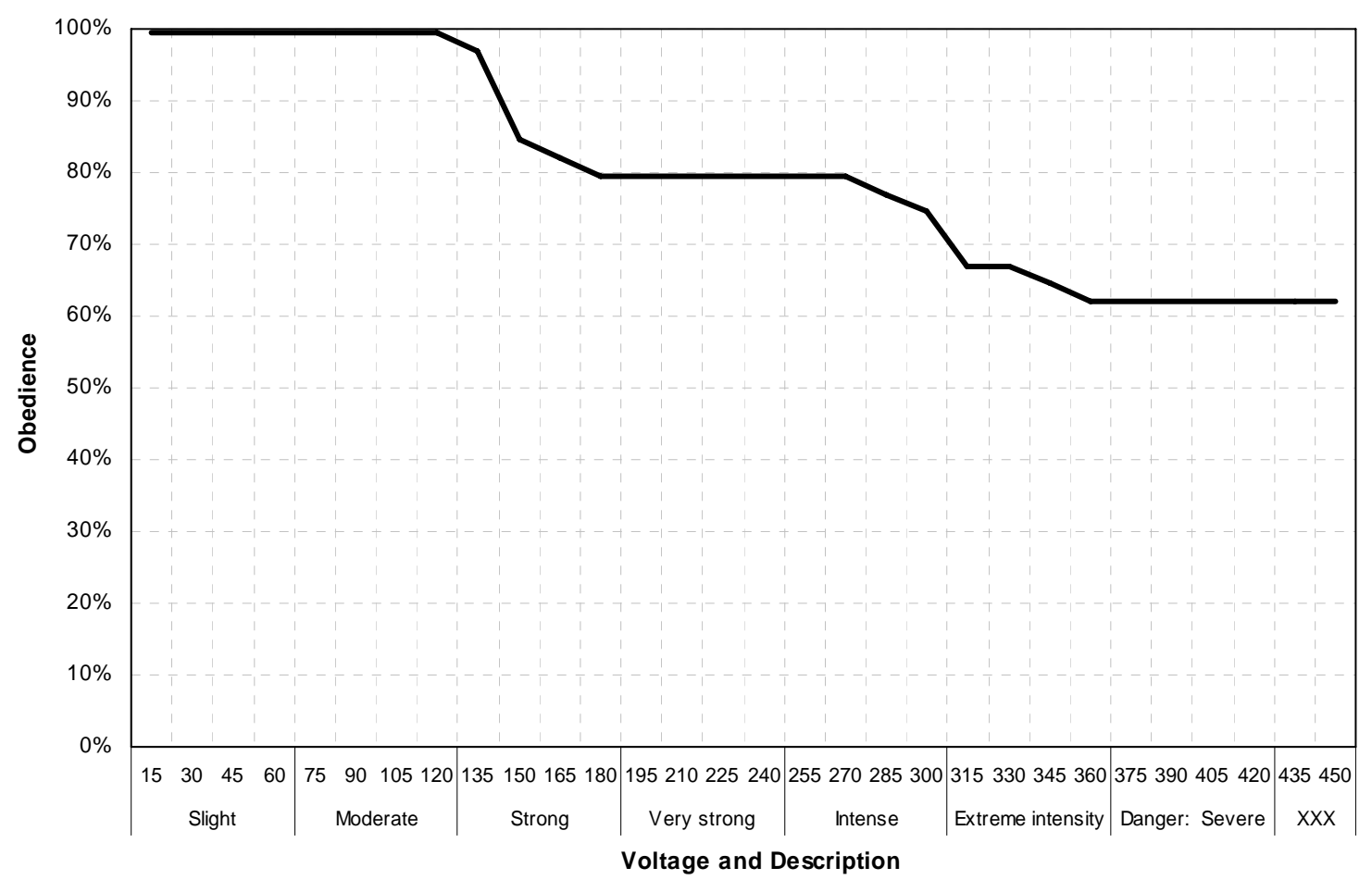

Source: Milgram (1974). 
Milgram repeated the experiment varying several parameters. For example, he found no difference in between male and female subjects. Moving the experiment from New Haven to Bridgeport had little effect. Placing the "learner" (actor) in more direct proximity to the "teacher" (true subject) did reduce obedience, but only marginally.

Milgram was so appalled by his findings that he never repeated the experiment in Germany. He concluded instead that human have a built-in propensity for loyalty - an urge to obey authority (Blass, 2004).

Milgram (1974) suggests that this urge has a genetic basis. Pre-human and early human hunters and gatherers who fell into line behind a tribal chief may well have had a significant survival advantage over otherwise biologically identical species composed of isolated individuals. Animals that hunt in packs, like wolves, also sort themselves into hierarchies, headed by so-called alpha males. Chimpanzees and Great Apes also spontaneously form hierarchies of dominance. Milgram's hypothesis that an analogous genetic impulse affects certain aspects of human behavior seems plausible, though little is actually known of its biochemical or genetic basis. Certainly, the hypothesis accords with early work in political economy, such as Hobbes (1652), arguing that submission to organized tyranny is preferable to independent savagery. Regardless, that we have built-in positive feelings associated with obedience to authority goes far to explain much of the misery and atrocity overlaying human history. ${ }^{4}$ We feel a sense of satisfaction from self-sacrificing acts of loyalty so profound that an innate biological basis seems likely.

Milgram followed up with the subjects of his experiments to understand why they behaved as they did (Blass, 2004). Many were profoundly upset by the experience, but common themes subjects used in justifying their actions were that they "gave their word" to the experimenter or felt a sense of "loyalty". Many indicated that they were "doing what was expected of them". Others indicated that failing to "live up to the expectations" of the

\footnotetext{
${ }^{4}$ See Bernardo and Welch (2001) for a discussion of group selection inducing seemingly irrational individual behavior in economics.
} 
experimenter was less acceptable than administering the shocks. Self-perceptions of "duty" and "loyalty" seemed to induce positive feelings and this promoted obedience. Since similar deep emotional responses are associated with other basic instinctive drives, Milgram's postulate of a neurological basis for obedience to authority seems plausible.

\section{Leadership and Corporate Governance}

In a modern liberal democracy, corporate head offices are prominent arenas for unfettered "leadership". Politicians are restrained by checks and balances and subject to the discipline of party whips. Judges are subject to reversal, bound by codes or precedent, and restrained by rules of procedure. But corporate CEOs can exercise leadership robustly. Short of violating the law, they can run their firms as they like. They can hire and fire lower level managers as they please, direct investment where they wish, and organize and reorganize their companies as they like.

Ideally, when a CEO proposes actions or strategies that are manifestly wrongheaded, experts in relevant fields should step forward to correct the error, or at least raise questions. But such people might be given pause by motion picture mogul Samuel Goldwyn’s famous bluster, “I don't want any yes-men around me! I want everyone to tell me the truth - even if it costs him his job!”

The board's explicit purpose is to hire, monitor, and - if necessary - fire the CEO. Corporate officers and directors in the United States have a formal fiduciary duty to intervene as necessary to protect public shareholders. That includes scaling back the CEO's pay if performance flags and firing seriously underperforming CEOs. But Mace (1986) shows that directors remain steadfastly loyal to misguided CEOs. The directors of Enron, WorldCom, Hollinger, Parmalat, and all the other companies currently embroiled in scandal attended regular meetings to favorably assess the performance of their CEOs. Despite increasing attention being 
drawn to their legal and ethical responsibilities, directors seem paralyzed in the presence of powerful CEOs.

To social psychologists, this paralysis is not surprising. Like the subjects who felt dutybound to administer high voltage electric shocks to perfect strangers, directors often feel an allegiance to the CEO. Criticizing a CEO, even for palpably awful decisions, smacks of “disloyalty”. Such a feeling is apparently to be avoided, even at considerable cost to one's conscience. Just as the "teacher" felt a need to meet the experimenter's expectations and electrocute the "learner”, directors may feel a need to "live up to” a hubristic CEO’s expectations and condone harm to public shareholders.

\section{Figure 3. Variant Experimental Designs}

When the "teacher" was required to hold the "learner's" hands against metal plates to administer the shock, obedience rates declined somewhat. At higher voltages, the "learner", a professional actor, feigns cried of agony.

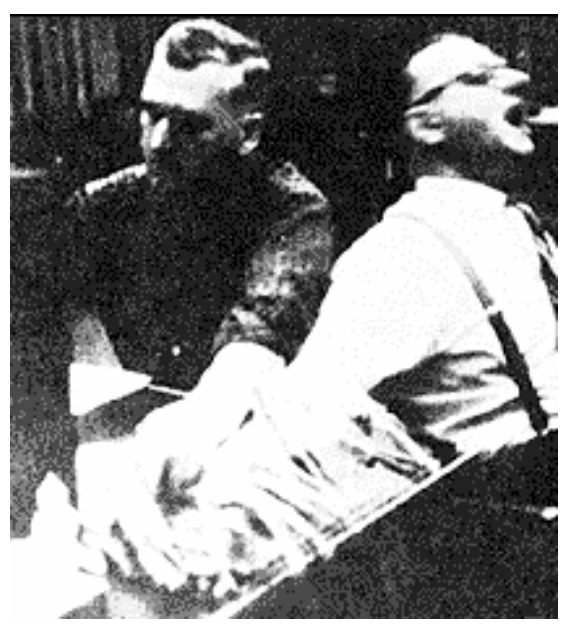

Source: Milgram (1974).

Why do directors' feelings of loyalty to the CEO outweigh their legal duty of loyalty to public shareholders? Public shareholders, the vulnerable widows and orphans of financial lore, are not present in the boardroom. Save one day each year, the annual general meeting, public shareholders are remote abstractions. Milgram found "teachers" more willing to administer shocks to more remotely located subjects - seated around a corner or in an adjacent room - than to subjects sitting nearer by. Figure 3 depicts a "close proximity" variant of the experiment, in 
which the "teacher" had to hold the "learner's" hands against metal plates while administering the shock. In this variant of, a lower percentage of "teachers (thirty percent) administered shocks all the way up to the maximum. In other variants, where the "learner" was around a corner or in a different room, a higher proportion of "teachers" administered maximum shocks than in the baseline experiment.

Jensen (1993, pp. 862-3) observes in his Presidential Address to the American Finance Association: "The problems with corporate internal control systems start with the board of directors. The board, at the apex of the internal control system, has the final responsibility for the functioning of the firm. Most importantly, it sets the rules of the game for the CEO. The job of the board is to hire, fire, and compensate the CEO, and to provide high-level counsel. Few boards in the past decades have done this job well in the absence of external crisis. This is particularly unfortunate given that the very purpose of the internal control mechanism is to provide an early warning system to put the organization on track before difficulties reach a crisis stage. The reasons for the failure of the board are not completely understood ....”

The Milgram results, applied to boardrooms, suggest directors obtain positive feelings from acts of loyalty to a proximate CEO perceived as a "leader". This reflexive obedience to authority is a plausible answer to Jensen’s (1993) puzzlement about why boards work so poorly so often. But given this, what reforms make sense to improve the functioning of boards?

\section{Dissenting Peers and Conflicting Authorities}

If the failure of the board is a consequence of fundamental aspects of human behavior revealed by the Milgram experiments, further knowledge about these aspects of human nature may hold keys to successful reform. Fortunately, Milgram performed many variations of his basic experiment.

Most of the variations Milgram performed, such as using women instead of men, adjusting the proximity of the "teacher" and the "learner", and so on, had at most only moderate 
effects on his results. However, two specific alternatives generated starkly different behavior on the part of the "teachers".

One of these features three "teachers" - one reads the question aloud, the second indicates if the answer was correct, and the third (the actual subject) throws the switch to initiate the shock. At 150 volts, the first "teacher" objects and walks out. The psychologist tells the subject to ask the questions and throw the electric switches. At 210 volts, the second "teacher" also refuses to continue. The psychologist then tells the subject to go on alone. The fraction of real subjects who continued administering shocks fell off sharply when these "dissenting peers" began voicing concerns. Milgram (1974, p. 118) notes that "The effects of peer rebellion are very impressive in undercutting the experimenter's authority.” Figure 4 illustrates.

\section{Figure 4. Obedience Rates, Dissenting Peers Variant}

Fraction of ordinary Connecticut residents directing electric shocks through perfect strangers, despite voiced concerns of two peers, when ordered to do so by a psychologist.

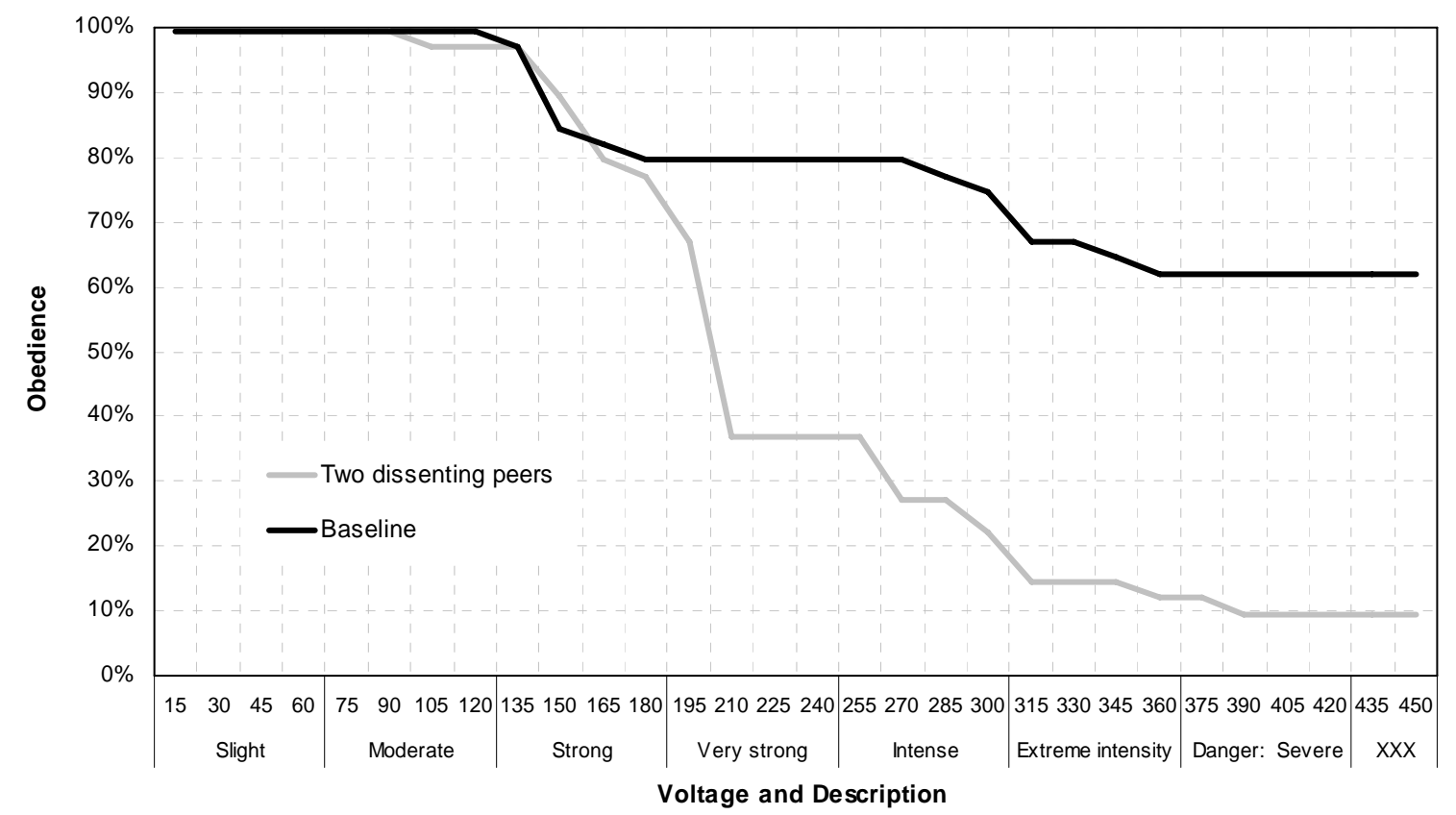

Source: Milgram (1974). 
Merely hearing someone else voice objections appears to be enough, in some cases at least, to overcome the human instinct of loyalty to legitimate authority.

Another variant led to a complete cessation of obedience halfway through the experiment. As in the baseline experiment of Figure 2, it featured only one "teacher". However, it now included two supervising psychologists "of approximately the same age and height.” At one hundred and fifty volts, one began a scripted argument that higher voltage was unnecessary, while the other argued for continuing the experiment to its end (p. 105). Confronted with discordant authority figures, the "teachers" sided with the psychologist who proposed ending the experiment in every case. Milgram (1974, p. 107) notes that “Not a single subject 'took advantage' of the opportunity to continue the shocks, and that "action was stopped dead in its tracks.” Figure 5 summarizes.

\section{Figure 5. Obedience Rates, Disagreeing Authority Figures Variant} Fraction of ordinary Connecticut residents directing electric shocks through perfect strangers when two psychologists disagree about the need to complete the experiment.

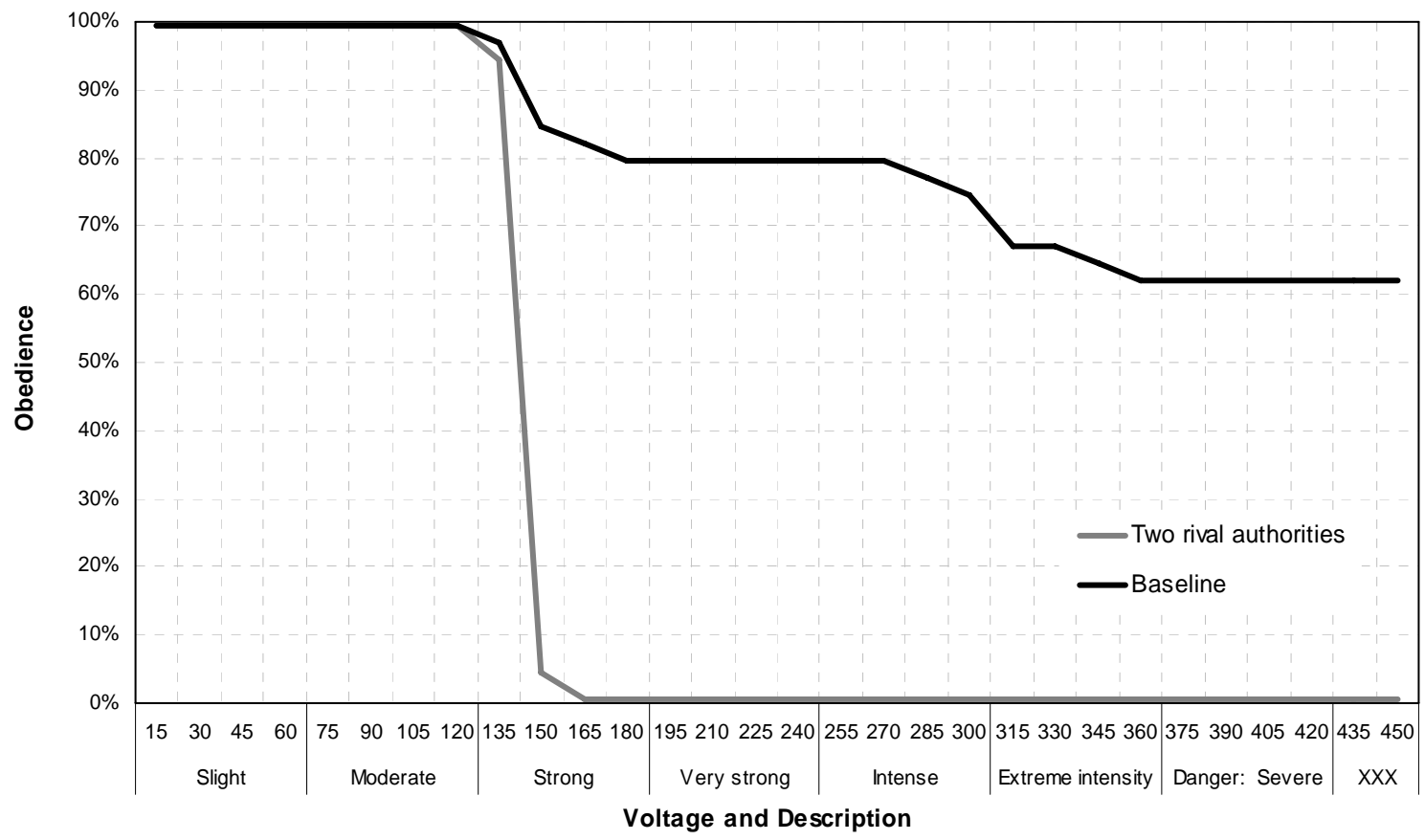

Source: Milgram (1974). 
Disputes between rival authority figures seem to undermine our willingness to obey authority and revitalize our willingness to weigh alternatives rationally and ethically. Authorities in conflict seem to evoke independent thought.

In further variants of this experiment, when Milgram (1974, p. 62) removed the experimenter from the lab, and had the "teacher" and "learner" receive instructions over a telephone, obedience dropped to about one third of the baseline level. Also, several subjects who continued administering shocks surreptitiously delivered lower voltage shocks that their instructions required. Some subjects actually assured the experimenter that they were delivering the shock levels required when they in fact were not. If the experimenter reentered the lab, this behavior ended and subjects resumed compliance. Milgram concluded that "[s]ubjects seemed able to resist the experimenter far better when they did not have to confront him face to face. ... The physical presence of an authority figure was an important force.”

\section{Encouraging Disobedience on Boards}

In variants of his experiments where Milgram arranged for "peers" to question the appropriateness of the experiment, obedience fell sharply. This suggests that independent directors, whose careers are not controlled by the CEO, might break the CEO's spell and permit a degree of disobedience by all the directors. Consistent with this, corporate governance reforms often strive to increase the number of independent directors on listed company boards or on key board committees. For example, the Sarbanes Oxley Act requires U.S. board to contain enough independent directors to staff key committees and the Higgs Report recommends that half of all U.K. directors be independent.

Independent directors seem to effect at least some governance pressure. Weisbach (1988) shows more CEO turnover after poor firm performance in firms with more independent directors; and Rosenstein and Wyatt (1990) find that share prices rise on news of outsiders joining boards. 
These results accord with independent directors playing the dissenting peers in Figure 4. However, a clear empirical link between independent directors and long-term firm performance remains elusive (Kang and Sorensen, 1999; Hermalin and Weisbach, 2003).

The variants of the Milgram experiment where obedience fell to zero involved rival experimenters, one pushing for continuation of the shocks and the other demanding that they stop. Consistent with this logic, the Higgs Report on corporate governance in the United Kingdom recommends that all boards have non-executive chairs and designate senior independent directors. That is, an independent director must chair the board and another must coordinate the activity of the other independent directors. Hopefully, either or both might serve as a rival authority figure to the CEO should the need arise.

Morck, Shleifer, and Vishny (1989) show that CEOs who simultaneously serve as CEO, president and chairman of the board are less likely than other CEOs to be replaced following poor firm performance. This is consistent with directors rationally evaluate CEO’s performance where rival authority figures exist, but obeying corporate czars holding three titles. Nonetheless, the relationship between rival authority figures and long-term performance is again unclear.

Variants of the Milgram experiment that removed the experimenter further from the “teacher's” immediate presence decreased obedience. This justifies provisions like that in the Sarbanes Oxley Act requiring audit committees solely of independent directors. By removing the CEO from these meetings, the reforms might induce greater disobedience and a more objective assessment of the company's financial state and future.

The Milgram experiments suggest that independent directors (like dissenting peers), nonexecutive chairs and lead independent directors (like arguing experimenters), and committees containing only independent directors (like subjects whose experimenter left the lab) ought to help free boards of reflexive obedience and stimulate rational debate (Herman, 1981; Mace, 1986; Wade et al. 1990). Yet conclusive evidence that long term performance is correlated with such governance structures remains elusive. 
One possible reason is that independent directors have not been common until very recently. For example, directors labeled independent might still represent the firm's lawyers, advertising agency, suppliers, or customers. These directors, though not personally financially tied to the firm or the CEO, represent interests with such ties.

More recent reforms stress more clearly the need for genuine independence. Thus, the Sarbanes Oxley Act of 2003 defines an independent director as "not receiving, other than for service on the board, any consulting, advisory, or other compensatory fee from the issuer, and as not being an affiliated person of the issuer, or any subsidiary thereof.” The Higgs report in the United Kingdom goes further, excluding people with "any material business relationship” with the company. Family ties, previous employment, and ties with major shareholders also preclude independence. These definitions may still be too loose. But perhaps, as genuinely independent directors become more common, a clear performance advantage will emerge.

A second possibility is that the Milgram experiments, though clearly relevant to corporate governance problems, are an incomplete guide to policy makers. Other behavioral responses may also come into play. These responses, like those found by Milgram, probably also result from evolutionary pressure favoring early human societies that could work better in groups. However, they can become dysfunctional in corporate board rooms, where they reinforce the directors' inclination to conform.

Corporate insiders who also serve as directors owe their careers and compensation packages to the CEO. Axelrod (1984) shows that humans reflexively repay favors. ${ }^{5}$ Consequently, insider directors are unlikely to oppose the CEO, even if she is patently wrong. Festinger (1957) finds that people's ethical standards are often swayed by their self-interest. Consequently, insider directors are likely to come to see their support for their CEO as highly ethically motivated.

\footnotetext{
${ }^{5}$ Such reflexive behavior is appreciated by students of marketing, such as Cialdini (1998), and motivates free samples and "no obligation" gifts as sales strategies.
} 
Many independent directors are still beholden to the firm's CEO. Shivdasani and Yermack (1999) find that boards contain fewer independent directors where CEOs control the nominating process, and that nominally independent directors in such firms often have financial ties to the CEO or the firm. It would be surprising if such financial ties did not affect these directors' judgment. And even directors with no such financial or other ties surely feel a sense of obligation to the CEO who appointed them, and a reflexive need to repay the favor. Even allegedly independent directors may find it hard to oppose the CEO and devise ethical justifications for their subservience.

One solution is to mandate that future independent directors be nominated by current independent directors. Another is to let institutional investors or public shareholders nominate directors. Both options have obvious drawbacks. If current independent directors are not really independent, they will appoint more of their own kind. Institutional investors may develop governance problems of their own. And public shareholders may be swayed by fads or famous names.

But even a substantial number of genuinely independent directors might not be sufficient to undermine the CEO's dominance. Asch (1951) shows that people tend to go along with a “group consensus” - even one rigged to be obviously wrong. Kahneman and Tversky (2000) summarize a large literature that shows people's decisions depend critically on how their options are "framed”. ${ }^{6}$ Even truly independent directors may feel a need to conform to a group consensus. The CEO sets the agenda for board meetings, and therefore can control how issues are "framed" to guide the formation of such a consensus - even in boards nominally dominated by genuinely independent directors.

The Higgs Report requires that the CEO not chair board meetings. These reforms seek to let an alternative authority figure frame issues. Again, such measures have costs. Entrusting too

\footnotetext{
${ }^{6}$ This knowledge is used by, for example, professional pollsters to generate answers that lend the aura of popular support to causes advanced by their clients. See Cialdini (1998).
} 
much control to an outsider could deprive the board of experience and knowledge. Moreover, Adams et al. (2005) argue that the CEO can manipulate agendas to frame issues most easily if she is the only insider on the board, and that boards entirely composed of independent directors actually strengthen the CEO's power. Ocasio (1994) argues that other corporate insiders on boards can emerge as alternative “leaders” if they feel they can usurp the CEO’s position.

Overall, the structure of corporate boards creates strong pressures on directors to fall into line behind the CEO. Fama (1980) and Fama and Jensen (1983) argue that directors seek to build reputations as effective monitors. However, such reputations may not be the key to successful careers as directors. A reputation as a "loose cannon" or a "troublemaker" may be a bigger impediment than a reputation as a “yes man” (Mace, 1971; Westphal and Stern, 2006, 2007).

\section{Alternative Explanations}

It is tempting to argue obedient directors and dominant CEOs must be an economically efficient outcome since this configuration is observed so consistently. If more constraints on CEOs were really economically sensible, would firms that found ways to impose such constraints not have flourished and grown to dominate the economy?

A rational agent explanation of Milgram's findings might derive from information cascades (Banerjee, 1992; Bikhchandi, Hirshleifer, and Welch, 1992), which occur when people rationally imitate a player who has already paid to become informed, rather than pay to become informed themselves. Thus, we presume more crowded restaurants have better food, and praise oeuvres of already lauded modern artists. From this perspective, Milgram's subjects initially assume the experimenter is informed and rationally opt not to pay the mental cost of thinking about what they are doing. When a second credibly informed experimenter voices dissent, the subjects opt to think and conclude their actions are irrational. 
Experimental studies show that information cascades can form in simple games (Anderson and Holt, 1997). The application of these findings in actual financial decision-making is unclear. While Drehmann et al. (2002) find experts at an international consulting firm as prone to information cascades as ordinary experimental subjects, Alevy et al. (2007) report options traders markedly less prone to information cascades than students, the typical subjects of experimental economic studies.

The plausibility of information cascades in finance is bolstered by their acceptance in other branches of economics. Long-term unemployment results if employers rely on applicants’ work histories, as opposed to gathering their own information (Kübler and Weizsäcker, 2003). Information cascades explain artistic success (Crossland and Smith, 2002) as well as runaway box office hits and flops in motion pictures (De Vany and Walls, 1996; though see also De Vany and Lee, 2001).

In finance, Amihud et al. (2003) show that Israeli IPOs are bimodal - either massively oversubscribed or pitifully undersubscribed - and propose information cascades to explain this. Rao et al. (2001) argue that information cascades explain financial analysts' decisions to initiate and discontinue coverage of particular stocks. The latter is perhaps consistent with Gul and Lundholm (1995), who extend information cascade models to allow endogenous timing of decisions, and predict waves of similar decisions, as agents strive to free-ride on fresh information.

Intriguingly, though information cascades might provide a rational agent explanation for the Milgram experiment, various studies propose that behavioral biases persist to damp information cascades. Thus, Noth and Weber (2003) propose that individually irrational overconfidence, by inducing agents to rely on their own judgment, deters information cascades. Kübler and Weizsäcker (2004) observe experimental subjects overpaying for signals, and suggest that this apparently irrational behavior might persist because it likewise damps information 
cascades. Arya et al. (2006) propose that noise in the information transmission process may be desirable because it can interrupt information cascades.

Thus, some mixture of rational and behavioral phenomena might explain Milgram's findings and the concordant issue of excessive loyalty in corporate boardrooms. However, there are several grounds for precluding information cascades as a complete explanation.

First, Martin et al. (1976) describe a modified Milgram experiment in which subjects in a boys' secondary school were directed to a set fake noise generator to a level indicating that they were exposing themselves to "a 50\% risk" of hearing damage. The close similarity of their findings to Milgram's implies obedience is not socialized aggression. Rationality seems implausible if the subjects truly believed were risking their own hearing. An innate and unthinking obedience reflex seems more consistent with this behavior.

Furthermore, Milgram's subjects stressed feelings of 'loyalty' and 'duty' in their ex-post debriefings; as well as respect for the experimenter's professional qualifications, which might proxy for superior information about the value of the experiment. This suggests behavioral motives in play.

Also, parallel work in political science by Janis (1972) attributes various political disasters - Kennedy's Bay of Pigs invasion of Cuba, the attack on Pearl Harbor, and America’s misadventures in Korea and Vietnam - to groupthink, defined as a psychological predisposition to conform to group expectations. While each of these fiascos might be attributed to an information cascade, detailed post-mortems expose clear psychological underpinnings. Independently of Milgram, Janis proposes a psychological urge to conform and speculates that it might be mitigated if groups assign members roles as critical evaluators, group leaders remain impartial, and multiple groups analyze issues independently. Surowiecki (2004) develops these concepts further, arguing that independence and freely voiced dissent let groups make superior decisions while the suppression of dissent induces groupthink. 
Finally, de Waal (2005) describes apes as organized into hierarchical social structures under alpha males (e.g. chimpanzees) or alpha females (e.g. bonobos), who command the obedience of other apes in the troop. Primates, including early hominids, who obey their alpha males (or females) might well survive better than those who pause to calculate the rational response to a charging mastodon. Thus, an obedience reflex, like other decision-making short cuts that seem irrational a priori, might contribute to individual or group survival. ${ }^{7}$ Evolutionary group selection can induce seemingly irrational individual behavioral biases (Bernardo and Welch, 2001), and ape parallels to human hierarchies are certainly consistent with Milgram's thesis of a biologically-based 'agency' instinct for loyalty.

Returning to corporate governance, obedience in corporate boardrooms might thus reflect behavioral biases, rational information cascades, or some interaction of the two. Regardless, popular attention to recent corporate governance scandals is inducing major institutional reforms aimed at altering the dynamics of board decision-making. Adams et al. (2005) show that powerful CEOs raise the variance in firm performance: some firms with powerful CEOs do much better than firms with constrained CEOs, others do much worse. Simply constraining the CEO thus probably confers no clear advantage. Good corporate governance requires constraints that fall into place when the CEO is making an obvious mistake, but not when he is enacting a visionary strategy. In practice, this distinction may be difficult for independent observers to draw. We are now engaged in economy-wide experiments in the United States, the United Kingdom, and elsewhere to see if various regulatory reforms can induce such discriminating constraints.

\footnotetext{
${ }^{7}$ Shiller (1995) speculates, based on the anthropology literature, that compliance and herding echo social conventions of polite conversation that enhance group survival odds. Brown and Levinson (1987) argue that such aspects of conversational politeness are standard across cultures, and that real tolerance of dissent requires effort and challenges human nature.
} 


\section{The Ethics of Corporate Governance}

Much popular discussion of corporate governance problems has a distinct moral tone. Corporate governance scandals are "ethical failures.” Milgram (1974, p. 7) found that "people ... asked to render a moral judgment on what constitutes appropriate behavior in [his experiments] unfailingly see disobedience as proper.” Asked why they behaved inappropriately, his subjects advanced excuses like politeness, keeping a promise, the awkwardness of disagreement, absorption in technical details of the experiment, or a belief that a greater good, like the advancement science, must justify the learner's pain. But the most universal response was a sense of loyalty to the experimenter. Milgram (1974, p. 8) concludes that his typical subject did not lose his moral sense; "Instead, it acquires a radically different focus. He does not respond with a moral sentiment to the actions he performs, Rather, his moral concern now shifts to a consideration of how well he is living up to the expectations that the authority has of him.”

Milgram (1974) posits what he calls an agentic shift, whereby individuals forsake rational reasoning for loyalty. Milgram (1974, p. 145-6) states “The most far-reaching consequence of the agentic shift is that a man feels responsibility to the authority directing him, but feels no responsibility for the content of the actions that the authority prescribes.” Directors enchanted by a powerful CEO feel a profound duty to live up to the CEO’s expectations, but none at all for how their actions affect shareholders, or other stakeholders for that matter.

Human nature changes slowly, if at all; and terms like loyalty and duty are laden with moral charge. Milgram (1974, p. 188) despairs that "The virtues of loyalty, discipline, and selfsacrifice that we value so highly in the individual are the very properties that create destructive engines of war and bind men to malevolent systems of authority.” Corporate governance scandals seem anticlimactic to this, but arise from the same weakness in human nature.

One hope whenever behavioral biases induce irrational or unethical behavior is that informing people about those biases can help them correct their errors and induce appropriate 
behavior. Gergen (1973, p. 313) argues in this vein that "sophistication as to psychological principles liberates one from their behavioral implications.” The Milgram experiments were highly publicized in the 1960s and 1970s, yet Schurz (1985) find no time trend in the findings of numerous subsequent studies replicating Milgram’s results. Proponents of education as liberation from behavioral influences may underestimate the difficulty of this task. Still, university ethics committees ended Milgram experiments in the 1980s, so longer trend estimates are unavailable. Corporate governance reforms and director education programs are now providing a natural experiment that holds the promise of greatly advancing our understanding of these issues.

\section{Agency Problems Revisited}

Shleifer and Vishny (1997) correctly argue that corporate governance problems often involve corporate insiders failing to act as agents of the firm's shareholders and other providers of capital. This view derives from the agency problem model of Jensen and Meckling (1976), in which corporate officers and directors have a duty as agents of shareholders, but act for themselves.

The phenomenon observed by Milgram (1974) is also a kind of agency problem. Indeed, Milgram dubs instinctive excessive obedience to legitimate authority agentic behavior. But here, the problem is individuals who ought to think and act for themselves instead serving as faithful agents. Thus, it may be sensible to conceive of two types of agency problem.

\section{Definitions A type I agency problem occurs if an individual acts for herself when social welfare would be higher if she acted as an agent. \\ A type II agency problem occurs if an individual acts as an agent when social welfare would be higher if she acted for herself.}

Jensen and Meckling (1976), and the agency problem literature in economics and finance, are concerned with type I agency problems. Milgram (1974) and the related social psychology literature are concerned with type II agency problems. 
In corporate governance, both sorts of agency problems occur. A type I agency problem occurs because top managers fail to act as faithful agents of the public shareholders, and follow their own unrestricted self-interest instead. But a type II agency problem also occurs when a director, who shares little in the CEO's excesses, nonetheless fall into line as his obedient agent. Improving corporate governance requires institutional changes that deal with both types of agency problem.

\section{Institutions to Balance Twin Agency Problems}

More generally, both types of agency problem occur throughout the economy and society. Individuals can err either by acting for themselves when they should act as agents of others, or by acting as agents when they should be thinking for themselves. Soldiers who pilfer from army stores constitute a type I agency problem; soldiers who fire on civilians when ordered to constitute a type II agency problem. Bureaucrats who waste taxpayers' money on pet projects are a type I agency problem; bureaucrats who obey their superiors to enforce patently foolish rules are a type II agency problem. Judges who misuse their offices to extract bribes are a type I agency problem; judges who rigidly enforce legalistic absurdities are a type II agency problem.

The balance of type I against type II agency problems probably affects institutional development in fairly basic ways. An early example is the Holy Office of the Devil's Advocate, a.k.a. the Promoter of the Faith, established by Pope Sixtus V in 1587. This early Counterreformation reform aimed to cleanse the Roman Church by vetting the character and miraculous credibility of sainthood candidates to stop powerful individuals from canonizing their friends and relatives. The office was only abolished by John Paul II in 1983, who then canonized five time more saints than all other $20^{\text {th }}$ century popes together.

A balancing of the dual agency problems also pervades legal and political institutions in the modern world. For example, the Common Law charges judges with interpreting general legal 
principles. This avoids making judges excessively obedient to political authorities, a type II agency problem, but some judges might abuse this power, a type I problem. French Civil Law, in contrast, requires judges to administer minutely detailed regulations, avoiding the type I problem, but inducing a vulnerability to type II problems. Glaeser and Shleifer (2002) argue that France’s more tumultuous early history exposed judges to bribes and threats by powerful litigants, escalated type I agency problems, wherein judges abandoned their duty to the people and ruled to accumulate private wealth. In Britain, Glaeser and Shleifer (2002) argue that judges were less subject to such pressures, and could therefore be trusted with more discretion. That is, the danger of type I agency problems in the judiciary was less, so institutions evolved to better limit type II agency problems.

A common theme, used across many different types of institutions to limit excessive obedience, is to create a formal and powerful official whose duty to criticize those, presumably to act as Milgram's rival authority figure and provoke the dramatic disruption of type II agency costs evident in Figure 5. Thus, Common Law courts employ the so-called Adversary System, pitting two lawyers against each other, charging each with an active duty to undermine the case advanced by the other. This was explicitly designed to limit judges' ability to manipulate the course of trails (Hostettler, 2006).

The Westminster model of parliamentary democracy likewise charges a Leader of the Official Opposition with the explicit duty of persistently criticizing the party power. This position evolved slowly after the Glorious Revolution as a way to limit first the power of the Kings and then the power of elected Prime Ministers (Fourd, 1964). Leaders of the Opposition were charged with disloyalty for voicing criticism of flawed policies with steadily falling frequency as the utility of open debate to good policy making ultimately won out - though a prestigious post for the loser in parliamentary elections no doubt also had its supporters.

Even in academia, we find appointed critics who are judged by their efficacy in finding mistakes in others' works - especially since the mid $20^{\text {th }}$ century. Each speaker at an academic 
conference must usually endure a subsequent ten minute critique by a discussant - another academic charged by the conference organizers with highlighting any and all the speaker's errors. Researchers seeking to publish their research must subject their work to the merciless criticism of anonymous academic referees, whose explicit duty is to expose errors in the research. Work unable to pass this test is generally not accepted as valid by other researchers. It be no coincidence that the pace of scientific progress hastened markedly after the mid-twentieth century when these procedures became institutionalized. Exploring how institutions develop and evolve to balance these twin agency problems in all manner of settings is an exciting avenue for future research.

The Law, government, and academia all developed institutions to check excessively zealous obedience to authority. This took centuries, even millennia, and we still have an occasional Guantanamo Bay established in the name of patriotism, an occasional Robert Mugabe running an economy into the ground amid cheering sycophants, and an occasional bogus stem cell paper by an eminent scientific authority. Eliminating all type II agency costs is most likely impossible, so a tradeoff emerges. Devoting sufficient resources to challenge every decision made is surely impossibly costly, so a degree of excessive loyalty persists, though we sometimes try to punish the overly loyal ex post. Hence, the disgrace, prosecutions, and financial ruin afforded soldiers who obey "illegal” orders, lackeys of ousted dictators, coauthors of disgraced scientists, and - of course - directors of Enron, WorldCom, and Hollinger.

This promise of a better balance seems especially great in corporate governance research. Arguably, no other career offers an aspiring leader the vast freedom of action entrusted to a corporate tycoon. Economists and psychologists are slowly groping towards better institutional arrangements for corporate governance that would disrupt excessively "agentic" behavior more effectively in corporations, yet not impose excessive costs on the economy or the individuals involved. In the aftermath of a spate of corporate governance scandals in the early 1930s, the United States passed the Securities and Exchanges Act mandating external audits of listed firms 
and created the Securities and Exchange Commission to enforce it. The New Deal architects of these reforms hoped sophisticated and powerful accounting firms would stand up to even the most mesmerizing of corporate leaders, but Arthur Anderson proved otherwise. Genuinely independent directors, lead independent directors, non-executive chairs, and the like are all alternative proposals for forcing open debate into boardrooms.

A consensus seems to be emerging that top corporate decision makers, like CEOs and controlling shareholders, need some analog to a Leader of the Official Opposition in Parliament or an academic discussant at an American Economic Association conference. At present, the form this analog will ultimately take is unclear, for which arrangements most effectively check excessively agentic behavior while imposing the least drag on economic activity remain ambiguous. Sarbanes-Oxley may well be too expensive, as its opponents charge (Leuz et al. 2007; Marosi and Massoud, 2007; Zhang, 2007; and others), and may soon be undone by a rising call for deregulation (Romano, 2005). ${ }^{8}$ A better balance may emerge from Britain’s self-regulation initiatives (Back and Coffee, 1994). Or we may wait for the next bout of corporate scandals to trigger entirely new reforms.

\section{Conclusions}

Behavioral issues are important in corporate governance. Milgram’s (1974) experiments in social psychology show that human nature includes a reflexive subservience to people perceived to be legitimate authorities, like corporate chief executive officers. This reflex disposes directors to fall into line behind their CEO. Because it connects to morally charged concepts like loyalty, trust, and duty, this subservience is difficult to overcome. Its moral overtone also lets people behave in overtly unethical ways, yet justify their behavior in terms of these charged concepts. This is consistent with directors justifying their acquiescence to obviously flawed corporate strategies in

\footnotetext{
${ }^{8}$ Though see Leuz (2007).
} 
terms of their loyalty to the CEO, his trust in them, and their duty to him. Other behavioral factors, such as cognitive dissonance, reciprocal favor trading, and group conformity, may significantly reinforce this subservience.

Effective corporate governance reforms must weaken this reflexive subservience. Milgram reports that dissenting peers, rival authorities, and absent authorities shook this subservience and reinitiated subjects’ own reasoning. Corporate governance reforms that envision independent directors (dissenting peers), non-executive chairs (alternative authority figures), and fully independent audit committees (absent authority figures) aspire to a similar effect on corporate boards - the initiation of real debate to expose poor strategies before they become fatal. In this vein, the United Kingdom's Higgs Report suggests that boards have "non-executive” chairs, and the Sarbanes Oxley reforms in the United States mandate audit committees composed solely of "independent” directors.

Given Milgram’s (1974) findings in social psychology and the large subsequent literature replicating them, the paucity of empirical evidence in the finance and economics literatures connecting such governance structures to corporate performance is puzzling. ${ }^{9}$ We suggest two plausible reasons.

One reason is that genuinely independent directors have been rarer than corporate proxy statements would suggest - at least until very recently. Many directors classified as independent are actually associated with the CEO. The Higgs report notes that roughly half of the British directors classified as independent are recruited by the CEO through personal contacts or friendships. As more stringent definitions of independence are applied, a clearer relationship with firm performance may emerge.

Another reason is that overcoming Milgram’s (1974) reflexive subservience may actually be quite difficult, especially if this behavior is reinforced by other innate behavioral responses. If so, genuinely independent directors and board chairs may require having institutional investors 
and public shareholders to nominate candidates for directorships. Such measures also entail other corporate governance risks, for they assume good governance within institutional investors and shareholder rationality. ${ }^{10}$ However, continuing corporate governance scandals over the years and throughout the world suggest that serious consideration be given to such reforms as ways of infusing more open debate and overt criticism of CEOs into corporate board meetings.

\section{References}

Adams, Renée, Heitor Almeida and Daniel Ferreira. 2005. Powerful CEOs and Their Impact on Corporate Performance. Review of Financial Studies 18(4) 1403-32.

Alevy, Jonathan, Michael Haigh, and John List. 2007. Information Cascades: Evidence from a Field Experiment with Financial Market Professionals. Journal of Finance 62(1) 151.

Amihud, Yakov and Shmuel Hauser, Amir Kirsh. 2003. Allocations, adverse selection, and cascades in IPOs: Evidence from the Tel Aviv Stock Exchange. Journal of Financial Economics 68(1) 137-58.

Anderson, Lisa and Charles Holt. 1997. Information cascades in the laboratory. American Economic Review 87(5) 847-62.

Arya, Anil, Jonathan Glover, and Brian Mittendorf. 2006. Hierarchical reporting, aggregation, and information cascades. Managerial and Decision Economics 27(5) 355.

Asch, Solomon. 1951. Effects of Group Pressure upon the Modification and Distortion of Judgment. In H. Guetzkow, ed. Groups, Leadership, and Men. Carnegie Press: Pittsburgh.

Axelrod, R. 1984. The Evolution of Cooperation. Basic Books.

Baker, Malcolm, Joshua Coval and Jeremy Stein. 2007. Corporate Financing Decisions When Investors Take the Path of Least Resistance. Journal of Financial Economics (forthcoming).

Baker, Malcolm and Jeffrey Wurgler. 2007. Investor Sentiment in the Stock Market. Journal of Economic Perspectives 21(2) 129-51.

Banerjee, Abhijit. 1992. A simple model of herd behavior. Quarterly Journal of Economics 107(3) 797-817.

Bernardo, Antonio, and Ivo Welch. 2001. On the Evolution of Overconfidence and Entrepreneurs. Journal of Economics and Management Strategy 10(3) 301-30.

Bikhchandaqni, Sahil, David Hirschleifer, and Ivo Welch. 1992. A theory of fashion, custom, and cultural change. Journal of Political Economy 100(5) 992-1026.

Black, Bernard and Jack Coffee. 1994. Hail Britannia? Institutional investor behavior under limited regulation. Michigan Law Review 92 1999-2088.

Blass, Thomas. 1998. A Cross Cultural Comparison of Studies of Obedience using the Milgram Paradigm. Unpublished. Cross cultural Milgram Studies.

Blass, Thomas. 2000. The Milgram paradigm after 35 years: Some Things We Know about obedience to Authority. In Thomas Blass, ed. Obedience to Authority - Current Perspectives on the Milgram Paradigm. Lawrence Erlbaum Associates, Mahwah NJ.

Blass, Thomas. 2004. The Man Who Shocked the World: The Life and Legacy of Stanley Milgram. Basic Books.

\footnotetext{
${ }^{9}$ See e.g. Hermalin and Weisbach (2003) for a recent survey.

${ }^{10}$ See e.g. Shleifer (2000).
} 
Brown, Penelope and Stephen Levinson. 1987. Politeness: Some Universals in Language Usage. Cambridge University Press.

Cialdini, Robert B. 1998. Influence: The Psychology of Persuasion. Quill.

Crossland, Philip and Faye Smith. 2002. Value creation in fine arts: A system dynamics model of inverse demand and information cascades. Strategic Management Journal 23(5) 417-34.

De Vany, Arthur and David Walls. 1996. Bose-Einstien dynamics and adaptive contracting in the motion picture industry. Economic Journal 106(439) 1493-1514.

De Vany, Arthur and Cassey Lee. 2001. Quality signals in information cascades and the dynamics of the distribution of motion picture box office revenues. Journal of Economic Dynamics \& Control 25(3/4) 593-614.

De Waal, Frans. 2005. Our Inner Ape: A Leading Primatologist Explains Why We Are Who We Are. Penguin.

Drehmann, Mathias, Jörg Oechssler, and Andreas Roider. 2002. Herding and Contrarian Behavior in Financial Markets: An Internet Experiment. American Economic Review 95(5)1403-26.

Fama, Eugene. 1980 Agency problems and the theory of the firm. Journal of Political Economy 88 288-307.

Fama, Eugene and Michael Jensen 1983. The separation of ownership and control. Journal of Law and Economics 26 301-25.

Festinger, L. 1957. A Theory of Cognitive Dissonance. Stanford University Press

Fourd, Archibald.1964. His Majesty’s Opposition, 1714 - 1830. Oxford University Press.

Gergen, K.J. 1973. Social Psychology as History. Journal of Personality and Social Psychology 26 309-320.

Glaeser, Edward and Andrei Shleifer. 2002. Legal Origins. Quarterly Journal of Economics 117(4) 1193.

Gul, Faruk, and Russel Lundholm. 1995. Endogenous timing and the clustering of agents' decisions. Journal of Political Economy 103(5) 1039.

Hermalin, Benjamin and Michael Weisbach. 2003. Boards of directors as an endogenously determined institution: A survey of the economic literature. Economic Policy Review Federal Reserve Bank of New York 9(1) 7.

Herman, Edward. 1981 Corporate Control. Corporate Power. Cambridge University Press.

Hobbes, 1651. Leviathan, or the Matter, Forme, and Power of a Commonwealth Ecclesiasticall and Civil. London: Andrew Crooke.

Hostettler, John. 2006. Fighting for Justice: The History and Origins of Adversary Trial. Waterside Press.

Zhang, Ivy Xiying. 2007. Economic consequences of the Sarbanes-Oxley Act of 2002. Journal of Accounting \& Economics 44(1/2) 74.

Janis, Irving. 1972. Victims of Groupthink: A Psychological Study of Policy Decisions and Fiascoe; republished as Groupthink: Psychological Studies of Policy Decisions and Fiascoes, Houghtom-Muffin, 1982.

Jensen, Michael and William. Meckling. 1976. Theory of the firm: Managerial behaviour, agency costs and ownership structure. Journal of Financial Economics 3 305-60.

Jensen, Michael. 1993. The modern industrial revolution, exit and the failure of internal control systems. Journal of Finance 48(3) 831-880.

Kahneman, Daniel and Amos Tversky. 2000. Choices, Values, and Frames. Cambridge University Press.

Kang, David and Aage Sorensen 19999. Ownership organization and firm performance. Annual Review of Sociology 25121 -1 44.

Kindleberger, Charles. 1976. Manias, Panics and Crashes.

Kübler, Dorothea and Georg Weizsäcker. 2003. Information Cascades in the Labor Market. Journal of Economics 80(3) 211-229. 
Kübler, Dorothea and Georg Weizsäcker. 2004. Limited Depth of Reasoning and Failure of Cascade Formation in the Laboratory. Review of Economic Studies 71(2) 425-441.

Lakonishok, Josef, Andrei Shleifer, Richard Thaler, and Robert Vishny. 1992. The Structure and Performance of the Money Management Industry. Brookings Papers on Economic Activity 1992(1) 339-92.

Laski, Harold J. 1919. The Dangers of Obedience. Harper’s Monthly Magazine 159 1-10.

Leuz, Christian. 2007. Was the Sarbanes-Oxley Act of 2002 really this costly? A discussion of evidence from event returns and going-private decisions. Journal of Accounting \& Economics 44(1/2) 146.

Christian Leuz, Alexander Triantis, and Tracy Wang. 2007. Why Do Firms Go Dark? Causes and Economic Consequences of Voluntary SEC Deregistrations. Journal of Accounting and Economics, forthcoming.

Martin, J, B. Lobb, Chapman, G. and R. Spillane. 1976. Obedience under conditions demanding self-immolation. Human Relation 29(4) 345.

Marosi, András and Nadia Massoud. 2007. Why Do Firms Go Dark? Journal of Financial and Quantitative Analysis 42(2) 421.

Merritt, A. and R. Helmreich. 1996. Human Factors of the Flight Deck: The Influence of National Culture. Journal of Cross-Cultural Psychology 27 5-24.

Mace, Myles. 1986. Directors: Myth and Reality. Harvard Business School Press.

Milgram, Stanley. 1963. Behavioral Study of Obedience. Journal of Abnormal and Social Psychology 67 371-378

Milgram, Stanley. 1974. Obedience to Authority. Harper and Row.

Miller, A.G. 1986. The Obedience Experiment: A Case Study of Controversy in Social Science. Praeger: NY.

Morck, Randall, Andrei Shleifer, and Robert Vishny. 1989. Alternative Mechanisms for Corporate Control. American Economic Review. 79(4) 842-852.

Noth, Markus and Martin Weber. 2003. Information aggregation with random ordering: Cascades and overconfidence. Economic Journal 113(484) 166-189.

Ocasio,W. 1994. Political Dynamics and the Circulation of Power: CEO Succession in U.S. Industrial Corporations, 1960-1990. Administrative Science Quarterly 39 285-312.

Rao, Hayagreeva, Henrich R Greve, and Gerald F Davis. 2001. Fool’s gold: Social proof in the initiation and abandonment of coverage by Wall Street analysts. Administrative Science Quarterly 46(3): 502-26.

Romano, Roberta. 2005. The Sarbanes-Oxley Act and the Making of Quack Corporate Governance. Yale Law Journal 1141521.

Schurz, G. 1985. Experimentelle Uberprüfüng des Zusammenhangs zwischen Persönlichkeitsmerkmalen und derBereitschaft zum destruktiven Gehorsam gegenüber Autoritäten. Zeitschrift für Experimentelle und Angewandte Psychologie 32`160-77.

Shiller, Robert. 1995. Conversation, information, and herd behavior. American Economic Review 85(2) 181.

Shivdasani, Anil and David Yermack. 1999. CEO Involvement in the Selection of New Board Members: An Empirical Analysis. Journal of Finance 54 1829-53.

Shleifer, Andrei and Robert W Vishny. 1997. A survey of corporate governance. Journal of Finance 52(2) 737-84.

Shleifer, Andrei. 1999. Inefficient Markets - An Introduction to Behavioral Finance (Clarendon Lectures in Economics). Oxford University Press.

Shleifer, Andrei and Robert Vishny. 2003. Stock market driven acquisitions. Journal of Financial Economics 70 295-311.

Surowiecki, James. 2004. The Wisdom of Crowds. Doubleday. 
Tarnow, Eugen. 2000. Self-Destructive Obedience in the Airplane Cockpit and the Concept of Obedience Optimization. In Thomas Blass, ed. Obedience to Authority - Current Perspectives on the Milgram Paradigm.

Weisbach, Michael S., 1988. Outside directors and CEO turnover. Journal of Financial Economics 20 431-460.

Westphal, James and Ithai Stern. 2006.The other pathway to the boardroom: How interpersonal influence behavior can substitute for elite credentials and demographic majority status in gaining access to board appointments. Administrative Science Quarterly 51 169-204.

Westphal, James and Ithai Stern. 2007. Flattery will get you everywhere (especially if you are a male Caucasian): How ingratiation, boardroom behavior, and demographic minority status affect additional board appointments at U.S. companies. Academy of Management Journal 50(2) 267-88. 